\title{
Desempenho de adultos jovens normais em dois testes de resolução temporal ${ }^{* * * * * *}$
}

\author{
Performance of normal young adults in two temporal resolution tests
}

\author{
Elena Zaidan* \\ Adriana Pontin Garcia** \\ Maria Lucy Fraga Tedesco*** \\ Jane A. Baran****
}

*Fonoaudióloga. Doutoranda em Audiologia pelo Department of Communication Disorders da University of Massachusetts Amherst. Endereço para correspondência: $\mathrm{R}$ Joaquim Floriano, 72 - cj 47 - São Paulo - SP - CEP 04534-000 (zaidan.pontin@uol.com.br).

**Fonoaudióloga. Mestre em Distúrbios da Comunicação Humana Campo Fonoaudiológico - Escola Paulista de Medicina (EPM) da Universidade Federal de São Paulo (Unifesp). Professora do Curso de Fonoaudiologia das Faculdades Metropolitanas Unidas.

***Fonoaudióloga. Doutora em Distúrbios da Comunicação Humana Campo Fonoaudiológico - EPM Unifesp. Coordenadora do Curso de Fonoaudiologia das Faculdades Metropolitanas Unidas.

****Fonoaudióloga. $\mathrm{PhD}$ em Audiology e Speech Sciences pela Purdue University. Professora and Chair do Department of Communication

Disorders, University of Massachusetts, Amherst.

****Trabalho Realizado no Centro Universitário das Faculdades Metropolitanas Unidas - University of Massachusetts Amherst.

Artigo Original de Pesquisa

Artigo Submetido a Avaliação por Pares

Conflito de Interesse: não

Recebido em 11.04.07.

Revisado em 10.07.07; 06.09.07;

12.10.07; 08.01.2008.

Aceito para Publicação em 11.01.2008.

\begin{abstract}
Background: temporal auditory processing is defined as the perception of sound or of sound alteration within a restricted time interval and is considered a fundamental ability for the auditory perception of verbal and non verbal sounds, for the perception of music, rhythm, periodicity and in the discrimination of pitch, duration and of phonemes. Aim: to compare the performance of normal Brazilian adults in two temporal resolution tests: the Gaps-in-Noise Test (GIN) and the Random Gap Detection Test (RGDT), and to analyze potential differences of performance in these two tests. Method: twenty-five college students with normal hearing (11 males and 14 females) and no history of educational, neurological and/ or language problems, underwent the GIN and RGDT at 40dB SL. Results: statistically significant gender effects for both tests were found, with female participants showing poorer performance on both temporal processing tests. In addition, a comparative analysis of the results obtained in the GIN and RGDT revealed significant differences in the threshold measures derived for these two tests. In general, significantly better gap detection thresholds were observed for both male and female participants on the GIN test when compared to the results obtained for the RGDT. Conclusion: male participants presented better performances on both RGDT and GIN, when compared to the females. There were no differences in performance between right and left ears on the GIN test. Participants of the present investigation, males and females, performed better on the GIN when compared to the RGDT. The GIN presented advantages over the RGDT, not only in terms of clinical validity and sensibility, but also in terms of application and scoring.
\end{abstract}

Key Words: Hearing; Loudness Perception; Adult.

\section{Resumo}

Tema: o processamento auditivo temporal se refere a percepção de um evento sonoro ou de uma alteração no mesmo, dentro de um intervalo definido de tempo e é considerado uma habilidade fundamental na percepção auditiva de sons verbais e não verbais, na percepção de música, ritmo e pontuação e na discriminação de pitch, de duração e de fonemas. Objetivo: realizar um estudo comparativo do desempenho de adultos jovens normais nos testes de resolução temporal, Random Gap Detection Test (RGDT) e Gapsin-Noise (GIN) e analisar diferenças entre esses dois métodos de avaliação. Método: 25 universitários, 11 homens e 14 mulheres, com audição normal e sem histórico de alterações educacionais, neurológicas e/ou linguagem, foram submetidos ao RGDT e ao GIN, a 40dB NS. Resultado: observou-se diferença estatisticamente significante entre os sexos sendo que as mulheres apresentaram pior desempenho nos dois testes. No estudo comparativo dos resultados do RGDT e GIN, observaram-se diferenças significativas no desempenho da amostra. De maneira geral, os limiares de detecção de gap no teste GIN foram melhores do que os limiares obtidos no RGDT. Conclusão: o sexo masculino teve melhor desempenho tanto no teste RGDT quanto no GIN, quando comparado ao feminino. Além disso, não houve diferença significante nas repostas do GIN nas orelhas direita e esquerda. Os sujeitos deste estudo tiveram melhor desempenho no teste GIN, quando comparado ao RGDT, tanto no sexo masculino quanto no feminino. Portanto, o teste GIN apresentou vantagens sobre o RGDT não apenas quanto à sua validade e sensibilidade, mas também com relação a sua aplicação e correção dos resultados.

Palavras-Chave: Audição; Percepção Sonora; Adulto. 


\section{Introduction}

Auditory temporal processing (TP) is defined as the perception of sound or of the alteration of sound within a restricted time interval (1). Temporal processing is considered a fundamental ability in the auditory perception of verbal and non-verbal sounds (2), in the perception of music, rhythm, and periodicity, and in pitch discrimination, duration discrimination, and phoneme discrimination $(3,4,5)$.

Temporal processing can be divided into categories that aid the understanding of some mechanisms and processes of the central auditory nervous system. Temporal resolution, one of these categories, is defined as the auditory system's ability to detect quick and sudden changes in the sound stimulus or the shortest time interval necessary to discriminate between two acoustic stimuli.

The simplest and most used method in temporal resolution research is gap detection, which is the perception of a brief interruption (silence interval) in a continuous sound stimulus $(1,6,7)$. The duration of each gap varies according to the psychoacoustic method used, but usually, the aim of these experiments is to establish the shortest gap interval that can be detected in the acoustic stimulus $(1,8)$. This shortest detectable interval is known as gap detection threshold. The gap detection threshold has been consistently obtained in the $2-6 \mathrm{~ms}$ interval (1).

Currently, there are two temporal resolution tests available in the market: the Random Gap Detection Test - RGDT (9) and the Gaps-In-Noise test - GIN (1).

The aim of the present work was to carry out a comparative study of the performance of normal young adults on the temporal resolution tests RGDT and GIN and to analyze differences between these two assessment methods.

\section{Method}

According to the current legislation referring to studies involving human beings, this research was approved by the Committee for Ethics in Research of FMU, protocol number 28/24CEP. All the assessed individuals signed the document of informed consent (Termo de Consentimento Livre e Esclarecido) after they had received information on the aims, the justification and the methodology of the proposed study.

The participants of the present study were 25 college students, 11 males and 14 females, who were between 18 and 29 years old. The females were enrolled in the speech pathology and audiology course and the males, in music therapy. The criterion used to form the study group was subjects with no history of auditory, educational, neurological and/ or language problems.

All the individuals were submitted to: standard pure tone audiometry battery, performed in a twochannel digital audiometer, model AC40 of Interacoustics; Speech Reception Threshold (SRT); and Word Recognition Score. Besides, all the participants were submitted to standard immitance battery by means of the middle ear analyzer model AZ7 of Interacoustics. All the participants who presented hearing thresholds below 25dBNA in the frequencies from 250 to $8,000 \mathrm{~Hz}$, type A tympanometric curve and acoustic reflexes in at least three frequencies were considered normalhearing persons.

Next, the individuals were submitted to the study's procedures, the Random Gap Detection Test (RGDT) and the Gaps-in-Noise Test (GIN), available in $\mathrm{CD}$. The Sony CD player was connected with the audiometer to control the assessment parameters. The tests were presented at $40 \mathrm{dBNS}$, from the average of 500, 1000 and $2000 \mathrm{~Hz}$.

The RGDT is a temporal resolution test that involves the binaural presentation of a gap embedded in pure tone in the frequencies from 500 to $4000 \mathrm{~Hz}$. The objective of this test is the determination of the shortest time interval that can be detected by the patient, that is, to determine the gap detection threshold. This interval or gap is measured in milliseconds ( $\mathrm{ms}$ ) and obtained by its perception in a series of stimulus pairs. The duration of the silence interval between each pair of pure tones increases and decreases randomly, varying in the interval of $0,2,5,10,15,20,25,30$ and $40 \mathrm{~ms}$. The participant was instructed to indicate whether he or she heard one or two stimuli. The first stimuli were used as training, and the others as the test (9). The determination of this threshold is calculated by the simple arithmetic mean of the results obtained in the four frequencies mentioned above.

The GIN is also a temporal resolution test that involves the monaural presentation of 0 - 3 gaps, with duration ranging from 0 to $20 \mathrm{~ms}$, embedded in segments of six seconds of white noise. The objective of this test is to determine the gap detection threshold, using, however, a different calculation method: Each gap duration occurs 6 times in each one of the lists, that is, along the lists, 6 gaps of $2 \mathrm{~ms}, 6$ of $3 \mathrm{~ms}, 6$ of $4 \mathrm{~ms}$ and so on are presented. The gap detection threshold is the 
shortest interval detected in 4 of the 6 presentations of a certain duration.

The GIN is composed of one training list and 4 test lists. All the participants completed the training and two of the four test lists, one for each ear. The participants were instructed to press the answer button connected with the audiometer whenever a gap was detected 3 .

This work used basically nonparametric tests, such as MANN-WHITNEY and WILCOXON. To complement the descriptive analysis, the CONFIDENCE INTERVAL technique was employed to calculate the mean and the significance level adopted was $5 \%$ (0.05).

\section{Results}

The responses obtained in the RGDT and GIN concerning the gender variable are displayed in Table 1. These responses were compared through the Mann-Whitney test.

Comparisons between the ears in the GIN test was made using the Wilcoxon test. The right ear mean was 5,38 ms (SD 2,39 ms) and left ear was 4,88 ms (SD 0,90). This analysis didn't show statistical difference. ( $\mathrm{p}$-value $=0,357$ ).

Genders were then compared in the GIN result, and this comparison was made for each year. In this analysis, the Mann-Whitney test was used (Table 2).

Finally, the results of the RGDT and of the GIN in the females and males were compared. This comparison was made for each gender and for each ear, that is, RGDT in relation to GIN RE, GIN LE and (Overall) GIN. The Mann-Whitney test was used (Table 3).

TABLE 1. Gender comparison in the responses obtained in the RGDT and GIN test.

\begin{tabular}{lcccc}
\hline & \multicolumn{2}{c}{ RGDT } & Male & Female \\
\hline Mean & Male & Female & 4,45 & 5,61 \\
\hline Median & 7,91 & 11,69 & 4,5 & 5 \\
\hline Standard Deviation & 7,5 & 10 & 0,76 & 2,17 \\
\hline Quartile 1 & 2,85 & 4,34 & 4 & 5 \\
\hline Quartile 3 & 6,88 & 7,90 & 5 & 6 \\
\hline Size & 9,38 & 14,38 & 20 & 28 \\
\hline CI & 11 & 15 & 0,33 & 0,80 \\
\hline p-value & 1,68 & 2,20 & & $0,008^{*}$ \\
\hline
\end{tabular}

TABLE 2. Comparative study of the responses obtained in the RGDT and in the GIN for each ear.

\begin{tabular}{|c|c|c|c|}
\hline Comparison & RGDT & GIN RE & GIN LE \\
\hline Mean & 10.09 & 5.38 & 4.88 \\
\hline Median & 8.75 & 5 & 5 \\
\hline Standard deviation & 4.18 & 2.39 & 0.90 \\
\hline Quartile 1 & 7.5 & 4 & 4 \\
\hline Quartile 3 & 12.5 & 5.25 & 5 \\
\hline Size & 26 & 24 & 24 \\
\hline $\mathrm{CI}$ & 1.60 & 0.96 & 0.36 \\
\hline$p$-value & & $<0.001 *$ & $<0.001 *$ \\
\hline
\end{tabular}


TABLE 3. Comparative study of the results obtained in the RGDT and in the GIN for each ear in the female and male gender.

\begin{tabular}{|c|c|c|c|c|}
\hline & \multicolumn{4}{|c|}{ Male Gender } \\
\hline & RGDT & GIN RE & GIN LE & GIN \\
\hline $\operatorname{san}$ & 7,91 & 4,40 & 4,50 & 4,45 \\
\hline dian & 7,50 & 4,50 & 4,50 & 4,50 \\
\hline ındard deviation & 2,85 & 0,97 & 0,53 & 0,76 \\
\hline Iartile 1 & 6,88 & 4,00 & 4,00 & 4,00 \\
\hline artile 3 & 9,38 & 5,00 & 5,00 & 5,00 \\
\hline \multirow[t]{3}{*}{ e } & 11 & 10 & 10 & 20 \\
\hline & 1,68 & 0,60 & 0,33 & 0,33 \\
\hline & & $0,005^{*}$ & $0,004 *$ & $0,001 *$ \\
\hline & \multicolumn{4}{|c|}{ Female Gender } \\
\hline & RGDT & GIN RE & GIN LE & GIN \\
\hline san & 11,69 & 6,07 & 5,14 & 5,61 \\
\hline dian & 10,00 & 5,00 & 5,00 & 5,00 \\
\hline Indard deviation & 4,34 & 2,87 & 1,03 & 2,17 \\
\hline lartile 1 & 7,90 & 5,00 & 5,00 & 5,00 \\
\hline artile 3 & 14,38 & 6,00 & 5,00 & 6,00 \\
\hline \multirow[t]{3}{*}{ e } & 15 & 14 & 14 & 28 \\
\hline & 2,20 & 1,50 & 0,54 & 0,80 \\
\hline & & $<0,001 *$ & $<0,001 *$ & $<0,001 *$ \\
\hline
\end{tabular}

\section{Discussion}

The administration of the temporal resolution tests, RGDT and GIN, to normal adults aimed to compare the performance of this population on the two studied tests and to analyze differences between these two assessment methods.

In the RGDT test, the mean gap detection threshold of the males $(7.91 \mathrm{~ms})$ was statistically better than the performance presented by the females (11.69ms). As far as we know, no studies in the literature report this gender difference in performance. However, if we consider that the male participants were music therapy students, we can put forward the hypothesis that the temporal resolution ability is more developed in musicians. In other words, working with musical instruments and melodies may require a more refined auditory perception. On the other hand, the two groups presented, on average, a poorer performance than the one reported by Chermak and Lee (10) and Manso et al. (11), in which the RGDT were administered to 44 young Brazilian females between
20 and 39 years-old with mean gap detection threshold of 10,01 ms.

Chermak and Lee (10) compared the performance of 10 normal children on the two temporal resolution tests, RGDT and GIN. The authors concluded that, from a clinical perspective, the four tests appropriately classified the children assessed as normal and they did not note statistically significant differences between GIN results and RGDT results. The mean gap detection for the population studied in the RGDT test, which is a binaural test, was 4.77 $\mathrm{ms}$, and in the GIN test, $4.6 \mathrm{~ms}$ (right ear) and $4.9 \mathrm{~ms}$ (left ear).

Ziliotto and Pereira (12) administered the RGDT test to 236 individuals with and without auditory processing problems, whose ages varied between 5 and 53 years. The mean gap detection threshold of the group without auditory processing problems was $6.74 \mathrm{~ms}$, while the mean calculated for the group which presented auditory processing problems was $32.13 \mathrm{~ms}$, a statistically significant difference. The 
authors suggested a mean gap detection threshold of up to $7.32 \mathrm{~ms}$ as the value to be considered normal, that is, any mean above this limit may be considered altered.

The performance of males and females in the temporal resolution test GIN also presented a statistically significant difference. Once again, the males' performance was better than the females'. This result does not corroborate the findings of Musiek et al. (1) whose study reported normative values, obtained in adults with normal hearing, a mean gap detection threshold of $4.9 \mathrm{~ms}$ and a standard deviation of $1 \mathrm{~ms}$.

On the other hand, this finding agrees with the results found by Samelli (13), whose male participants also presented better gap detection thresholds when compared to the female participants in the GIN test, for both ears. The author found the mean gap detection of $4 \mathrm{~ms}$ in the GIN test in a study involving 100 normal Brazilian adults. The study found statistically significant gender effects on the subjects' performance on the test; however, no difference was found in performance between right and left ears.

There were no significant differences in performance between right and left ears, which agrees with previously reported findings $(1,10,13)$. As regards the gap detection thresholds, the mean of the results of the male participants confirms the values found in other studies $(1,10,13)$. The females, in turn, presented a mean gap detection threshold that was slightly higher than the one found by studies that investigated the gap detection paradigm $(10,14,15,16)$. On the other hand, if we consider the studies that administered the GIN test to adults $(1,13)$, the results found in the present study for the females still are within normal standards.

In the comparative study of RGDT and GIN results, significant differences were observed in the performance of the sample: the gap detection thresholds in the GIN test were better that the thresholds obtained in the RGDT. Only one work in the literature compared the performance of individuals with normal development in these two tests (10), and it did not find differences between the means of the gap detection thresholds. This disagreement between the two studies may have occurred due to differences in the size and age of the sample. Chermak and Lee (10) studied only 10 children from 7 to 11 years of age, while the present work administered the tests to more than 20 young adults. Furthermore, it is important to mention that the thresholds found in the RGDT test are higher than those reported in other works $(10,11)$. This did not happen with the GIN results $(3,10,13)$. Finally, the difference between the types of stimuli used in each test, white noise in the GIN test and pure tone in the RGDT test, may be responsible for this significant difference between the means of gap detection thresholds between the two tests. Researchers who employed broadband noises or high frequency pure tones $(17,18)$ reported better gap detection thresholds than those who used low frequency pure tones $(19,20)$.

Differences between the two tests were observed during this study and may influence the professional's decision to use one test or the other in his/her clinical practice. Although the RGDT is characterized by its ease of test administration and scoring, the method used to determine the gap detection threshold is based on just nine presentations of different durations per frequency. Thus, if the individual correctly identifies items with intervals of 5 and $10 \mathrm{~ms}$ and loses concentration in one presentation whose gap is $15 \mathrm{~ms}$, his/her threshold will be determined in any value correctly identified above $15 \mathrm{~ms}$, that is, between 20 and 40 ms. This may result in a false-positive diagnosis for an alteration in the temporal resolution ability. In the case of the GIN test, this would be more difficult to occur, since the determination of the threshold, 4 correct identifications in 6 presentations of one gap of certain duration, is more consistent with threshold definitions described by Russo (21).

The type of response required in the GIN test, pressing a button or just indicating whenever a gap is perceived, also minimizes possible confusions during the exam. In the RGDT, counting the number of stimuli or answering verbally may be more challenging, from a cognitive perspective.

Finally, the GIN assesses separately the right and left auditory channels, which is important information in the assessment of children and elderly individuals. Besides, preliminary results show validity, specificity and sensitiveness in the identification of patients with confirmed central auditory nervous system involvement (1). On the other hand, no research was effectively carried out to study the validity of the RGDT test as a measure of the temporal resolution ability. On the contrary, Keith (9) used previously collected data during the development of the AFTR test (22) to establish the validity of the RGDT: the author compared the individuals' performance on both tests, found similar results and based on these data, established the normality criteria for the $\operatorname{RGDT}(22,23)$. 


\section{Conclusion}

The critical analysis of the results referring to the responses obtained in the RGDT and GIN tests allowed us to conclude that:

. the male participants showed better performance on both the RGDT and the GIN tests, when compared to the results obtained for the female participants;

\section{References}

1. Musiek FE, Shinn JB, Jirsa R, Bamiou DE, Baran JA, Zaidan E. GIN (gaps in noise) test performance in subjects with confirmed central auditory nervous system involvement. Ear \& Hearing. 2005;26(6):608-18.

2. Bellis TJ. Assessment and management of central auditory processing disorders in the educational setting: from science to practice (2nd ed.). New York: Delmar Learning; 2003.

3. Downie ALS, Jakobson LS, Frisk V, Ushycky I. Auditory temporal processing deficits in children with periventricular brain injury. Brain and Language. 2002;80:208-25.

4. Phillips DP. Central auditory system and central auditory processing disorders: some conceptual issues. Seminars in Hearing. 2002;23:251-61

5. Rupp A, Gutschalk A, Hack S, Scherg M. Temporal resolution of the human primary auditory cortex in gap detection. Neuroreport. 2002;13(17):2203-7.

6. Schneider BA, Hamstra SJ. Gap detection thresholds as a function of tonal duration for younger and older listeners. Journal of the Acoustical Society of America. 1999;106(1): 371-80.

7. Boets B, Wouters J, van Wieringen, A, Ghesquière P. Auditory temporal information processing in preschool children at family risk for dyslexia: Relations with phonological abilities and developing literacy skills. Brain and Language. 2006;97:64-79.

8. Gelfand SA, Hoffman S, Waltzman SB, Piper N. Dichotic $\mathrm{CV}$ recognition at various interaural temporal onset asynchronies: effect of age. Journal of the Acoustical Society of America. 1980;68:1258-61.

9. Keith R. Random gap detection test. St. Louis, MO: Auditec; 2000

10. Chermak GD, Lee J. Comparison of children's performance on four tests of temporal resolution. Journal of the American Academy of Audiology. 2005;16:554-63.

11. Manso A, Bastidas CSG, Queiroz DS, Branco FCA. Desempenho de adultos do sexo feminino no teste de detecção de gap. São Paulo: Anais do 17o Encontro Internacional de Audiologia; 2002.

12. Ziliotto K, Pereira LD. Random gap detection test in subjects with and without APD. Trabalho apresentado no 17th American Academy of Audiology - Annual Convention and Exposition. Washington, DC - EUA; 2005. p. 30.
. there was no significant difference in performance between right and left ears on the GIN test; . the participants in the present investigation, both males and females, performed better on the GIN test when compared to the RGDT; . the GIN test presented advantages over the RGDT test, both in terms of its clinical validity and its ease of test administration and scoring.

13. Samelli AG. O Teste GIN (gap in noise): limiares de detecção de gap em adultos com audição normal. São Paulo, Tese de doutorado apresentada a FMUSP; 2005.

14. Phillips DP. Auditory gap detection, perceptual channels and temporal resolution in speech perception. Journal of the American Academy of Audiology. 1999;10(6):343-54.

15. Green DM. Temporal Factors in Psychoacoustics. In: Time Resolution in Auditory Systems. Michelsen A. (Ed.). London: Springer; 1985.

16. He NJ, Horwitz AR, Dubno JR, Mills JH. Psychometric functions for gap detection in noise measured from young and aged subjects. Journal of the Acoustical Society of America. 1999;106(2):966-78

17. Shailer MJ \& Moore BCJ. Gap detection as a function of frequency, bandwidth and level. Journal of the Acoustical Society of America. 1983;74:467-73.

18. Moore BJ, Peters RW \& Glasberg BR. Detection of temporal gaps in sinusoids: Effects of frequency and level. Journal of the Acoustical Society of America. 1993;93:1563-70.

19. Hall JW, Groose JH \& Joy S. Gap detection for pairs of noise bands: Effects of stimulus level and frequency separation. Journal of the Acoustical Society of America. 1996;99:1091-5.

20. Phillips DP, Taylor TL, Hall SE, Carr MM \& Massop JE. Detection of silent intervals between noises activating different perceptual channels: Some properties of "central" auditory gap detection. Journal of the Acoustical Society of America. 1997;101:3694-705.

21. Russo ICP. Acústica e psicoacústica aplicadas à

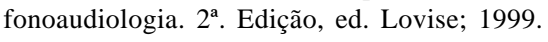

22. McCroskey RL, Keith RW. Auditory Fusion TestRevised (AFT-T), Auditec of St. Louis; 1996.

23. McCroskey RL, Kidder HC. Auditory fusion among learning disabled, reading disabled, and normal children. Journal of Learning Disabilities. 1980;13:18-25. 